\title{
Autumn
}

\section{Laura Main}

Ruth SLOWLY Rose from the wicker chair and moved toward her easel. How many different canvases had rested there? Paintings of old dogs, landscapes and dreams. She ran her battered fingers along the edge of her new work. She had been taking her time with this piece. It had meaning that she didn't completely understand. It was her first new piece since Tom had died on the first day of winter last year. She couldn't rush this one.

It was a painting of a park. Every night in her dreams she had gone there. An abundance of autumn leaves littered the ground. Bold reds and warm golden colours fluttered down from the near naked trees to lie by her feet. The dew on the remaining branches slowly trickled down to the ground below. Ruth felt warmth run through her body when she thought of this place. She had a desire to cross the threshold of the great iron gates and enter into its mystery.

Ruth liked to ride the bus. Sitting high among the other passengers she watched the city goers run about the streets. Couples holding hands and people in drab greys bustled in and out of buildings. She wasn't missing out on anything that she had steadfastly avoided for the past fifty years. Ruth heard younger women voicing their dislike for the colder months. They wanted summer to arrive so they could fry their skin and wear next to nothing as they frolicked in the water. They had no love for autumn.

Ruth took refuge in the darker overcast days. The light disappeared 
earlier meaning she could sit sooner before the fire and reminisce about times gone by. She had no desire to be hot and sticky. The restlessness of those balmy nights were well and truly behind her. Days that dragged on well into the night were not welcome.

She felt the season. The shedding of the memories, letting them blossom in her mind and then watching them drift softly to her feet. She could see them all fading away. She was releasing her hold, enjoying being able to remember less. Battening down the hatches, waiting for winter to come and embrace her like an old friend. All she could think of was walking toward the oncoming season and its inviting darkness with open arms.

Ruth thought of the canvas back home. It was where she wanted to be. She sat back on the bus and wished Tom was there with her, holding her hand, talking about the vegie patch and admiring the weather. Oh how she wanted to feel his presence. His warmth and comfort that no blanket or hot water bottle could match. He knew everything there was to know about her. He knew every crease in her face, every scar on her body.

The bus was travelling away from the city in a direction she was not sure she had travelled before. More and more trees whistled past as they drove further into the countryside. She saw a sign for parklands and motioned for the driver to let her off. She would sit here for the remainder of the afternoon and paint. She stepped off and looked at the park. A sense of calm came over her. It felt so familiar.

The trees loomed tall and it came to her how she knew this place. It was the winterland she dreamt of when the nights became too much. Ruth walked toward the entrance and anticipation swelled within her. Tom must be waiting inside. The wrought iron gates stood before her, engraved with intricate maze-like detail. They begged for her to open them. To take a step inside. She wanted to walk beneath the leaves before they fluttered to the ground. The trees whispered, inviting her with the wind. Her steady hand reached for the gate.

She was one step closer to winter. 